\section{Marine Biology}

Volume 152, Number 2 / AUG 2007: 441-447

http://dx.doi.org/10.1007/s00227-007-0703-3

(c) 2007 Marine Biology
Archimer, archive institutionnelle de l'Ifremer http://www.ifremer.fr/docelec/

The original publication is available at http://www.springerlink.com

\title{
Toxic dinoflagellates (Alexandrium fundyense and A. catenella) have minimal apparent effect on oyster hemocytes
}

\author{
Hélène Hégaret ${ }^{1 *}$, Gary H. Wikfors ${ }^{2}$, Philippe Soudant ${ }^{3}$, Christophe Lambert ${ }^{3}$, Sandra E. \\ Shumway ${ }^{1}$, Jean Baptiste Bérard ${ }^{4}$, Patrick Lassus ${ }^{4}$ \\ ${ }^{1}$ University of Connecticut, Marine Science Department, 1080 Shennecossett Road, Groton, CT 06340 USA \\ ${ }^{2}$ NOAA Fisheries, Northeast Fisheries Science Center, 212 Rogers Avenue, Milford, CT 06460 USA \\ 3 LEMAR UMR 6539, IUEM-UBO, Place Nicolas Copernic, Plouzané, France. \\ ${ }^{4}$ IFREMER, BP 21105, Nantes, F-44311 France
}

Corresponding author : Gary H. Wikfors

Email: Gary.Wikfors@noaa.gov

Phone: 2038826525

Fax: 2038826517

\begin{abstract}
:
The possible effect of Alexandrium spp. containing paralytic shellfish poisoning (PSP) toxins on the hemocyte parameters of oysters was tested experimentally. In separate experiments, eastern oysters, Crassostrea virginica, were exposed to bloom concentrations of the sympatric dinoflagellate, Alexandrium fundyense, alone and in a mixture with a non-toxic diatom, Thalassiosira weissflogii, and Pacific oysters, Crassostrea gigas, were exposed to a mixed suspension of the sympatric, toxic species Alexandrium catenella, with $T$. weissflogii. Measurements of numbers of oyster hemocytes, percentages of different cell types, and functions (phagocytosis, reactive oxygen species - ROS -production, and mortality) were made using flow-cytometric methods. During and after exposure, no significant effect of Alexandrium upon hemocyte numbers, morphology, or functions were detected, despite observations of adductor-muscle paralysis in eastern oysters and measured toxin accumulation in $C$. gigas. Significant effects of physical displacement of oysters into the experimental conditions and of temperature (repeated at 12 and $18^{\circ} \mathrm{C}$ ) upon immune status were detected in Pacific oysters. Correlations between hemocyte numbers and function were consistent with previous studies and were representative of normal, unstressed oysters. The finding of no effect of toxic Alexandrium spp. upon oyster hemocytes is consistent with the knowledge that PSP toxins interfere specifically with sodium-channel function in neural tissues and supports the expectation that sodium-channel physiology has no importance in hemocyte functions in oysters. Finally, we found no evidence of bioactive compounds, other than PST, in the two species of Alexandrium studied.
\end{abstract}




\section{Introduction}

Paralytic shellfish poisoning (PSP) toxins are produced by a number of dinoflagellates including Alexandrium spp. (formerly included in the genus Protogonyaulax or Gonyaulax), Gymnodinium catenatum, and Pyrodinium bahamense. Suspension feeders, such as bivalve molluscs, are the principal vectors transferring these phytotoxins to humans and other consumers of shellfish, as bivalves accumulate toxins from the toxic algae they consume (Bricelj and Shumway 1998). Capacity to accumulate PSP toxin differs among bivalve species (Shumway et al., 1988; Gainey and Shumway 1988a; Bricelj and Shumway 1998; Bricelj et al., 2005). For example, when exposed simultaneously to a toxic algal bloom, oysters accumulated lower levels of toxins than did mussels (Lassus et al., 1999).

Despite apparent tolerance of accumulated PSP and other toxins in their soft tissues, some bivalves may have reduced survival and growth (Shumway 1990). Other studies provide evidence of sub-lethal effects, such as reduced clearance rates in juvenile bay scallops (Argopecten irradians irradians), northern quahogs (Mercenaria mercenaria), soft-shell clams (Mya arenaria), blue mussels (Mytilus edulis), and flat oysters (Ostrea edulis) in the presence of toxic Alexandrium sp. cells (Lesser and Shumway 1993). Similarly, Lassus et al. (1996) reported reduced clearance rates in Pacific oysters (Crassostrea gigas) exposed to A. tamarense and Shumway and Cucci (1987) demonstrated its effects on shell-valve closure and mucus production in several bivalve species. Changes in heart rate of bivalves have also been observed in the presence of $A$. tamarense (Gainey and Shumway 1988b). Li et al. (2002) showed a decline in the clearance rate of the clam Ruditapes philippinarum exposed to highly-toxic $A$. tamarense, and decreases in absorption efficiency of both clams $(R$. philippinarum) and mussels (Perna viridis) coincident with toxin accumulation. Depending upon the bivalve species, morphological effects of accumulated paralytic phycotoxins from $A$. tamarense are seen in different organs, especially in the digestive gland and the kidney, and less commonly in other organs, such as the adductor muscle and the gonad (Lassus et al., 1999; Bougrier et al., 2001; Choi et al., 2003). These diverse effects of PSP-containing dinoflagellates on bivalve molluscs suggest that other aspects of physiological processes may also be affected.

Invertebrates, including bivalves, have no acquired immunity and are therefore limited to an innate immune response to pathogens, parasites, and physical injury (Janeway 1994), which is mediated by chemical agents and specialized cells called hemocytes circulating throughout the body. Hemocytes recognize and attempt to eliminate non-self particles within an open vascular system and tissues, but they do not "remember" a prior experience with a harmful agent and more effectively protect an individual in subsequent exposures. Recent studies in the laboratory and in the field (Hégaret et al., $2005 \mathrm{a}$; b) of effects of the harmful dinoflagellate Prorocentrum minimum on bivalves were the first to show effects on hemocytes. These effects included changes in morphological and functional parameters, such as: concentrations and proportions of the different hemocyte types, production of reactive oxygen species, phagocytosis or the percentage of dead hemocytes in eastern oysters (Crassostrea virginica) and northern bay scallops ( $A$. irradians). The bioactive compound or compounds in $P$. minimum responsible for these effects have not been identified. In the present study, we evaluated hemocyte characteristics and functions in: (1) C. virginica exposed to $A$. fundyense, two species that co-occur on the east coast of North America, and (2) C. gigas exposed to A. catenella, species that co-occur in western Europe. Experimental exposures used cultured algae and included additional variables, such as algal cell density, combination with non-toxic algae, and temperature. The two experiments were done independently and, in part, for different purposes. Thus, there were some differences in experimental design and protocols for hemocyte-parameter analyses.

\section{Materials and methods}

Two experiments were conducted in which oysters were exposed to cultures of toxinproducing strains of dinoflagellates, Alexandrium spp., and then analyzed for hemocyte parameter changes: one was conducted in May 2004 at the Milford Laboratory (Connecticut, USA), and another was done in June 2004 at the IFREMER facility in Nantes (France). Eastern oysters, Crassostrea virginica Gmelin, were studied in Milford, and Pacific oysters, Crassostrea gigas Thunberg, were studied in Nantes. 


\subsection{Experimental oysters}

Eastern oysters, Crassostrea virginica, obtained from the F.M. Flower Hatchery (Oyster Bay, New York, USA), were used in the Milford experiment. Before being transferred to experimental basins, oysters (ca. $30-\mathrm{mm}$ shell height) were conditioned in running, unfiltered seawater $\left(17^{\circ} \mathrm{C}\right)$ in the Milford Laboratory. These oysters were not gametogenic.

Triploid Pacific oysters, Crassostrea gigas, used for the two experiments in Nantes were obtained from a producer in Le Croisic, France. These oysters were produced by the hatchery Vendée Naissain, and were grown in basins. The experimental oysters $(9.1 \pm 1.6 \mathrm{~g}$ wet weight, ca. $60 \mathrm{~mm}$ shell height) were acclimated in basins containing running seawater for $6 \mathrm{~d}$ at the experimental temperature of $16 \pm 0.5^{\circ} \mathrm{C}$ and were transferred into experimental units after being cleaned. Triploid oysters were chosen because, compared to diploids, they are thought to have faster growth and better survival for aquaculture production (Nell 2002). Moreover, triploids do not produce gametes, which, if present at the time of the experiment, could interfere with hemocyte analyses by contaminating hemolymph samples.

\subsection{Algal cultures}

For the experiment in Milford, strains of Alexandrium fundyense Balech (BF 2) and non-toxic Thalassiosira weissflogii (Grun.) Fryxell et Hasle (TW) were obtained from the Milford Laboratory Microalgal Culture Collection. This strain of $A$. fundyense causes mortality in bay scallops after 24-h exposure to stationary-phase cells (Hégaret and Wikfors 2005a). Both BF 2 and TW contain bacterial contaminants, but cultures were managed aseptically to preclude contamination with additional microbes. Strain TW was cultured in the "E+Si Medium" seawater enrichment of Ukeles (1973) at a salinity of 15; BF 2 was cultured in E medium at 30 . Carboy cultures, grown under continuous illumination $\left(300 \mu \mathrm{E} \mathrm{m} \mathrm{m}^{-2} \mathrm{~s}^{-1}\right.$ ) in a temperature-controlled $\left(18^{\circ} \mathrm{C}\right)$ room, were managed semicontinuously, with half the volume harvested and replaced aseptically every $7 \mathrm{~d}$.

For the experiment in Nantes, strains of Alexandrium catenella (Whedon et Kofoid) (ATTL01) and T. weissflogii were batch-cultured in $10-\mathrm{I}$ carboys at $16^{\circ} \mathrm{C}$, with a light intensity of $50 \mu \mathrm{E} \mathrm{m} \mathrm{m}^{-2} \mathrm{~s}^{-1}$ and a $12 \mathrm{~h}$ light: $12 \mathrm{~h}$ dark cycle. A. catenella was cultured in $\mathrm{f} / 2$ medium (Guillard and Rhyther 1962); the $T$. weissflogii culture was grown in natural seawater filtered to $0.22 \mu \mathrm{m}$ and enriched with ES nutrients (Provasoli 1966). The A. catenella strain ATTL01 was isolated from the Thau basin in 1998 (Lilly et al., 2002) and contained 5-15 pg saxitoxin equivalent (eq.STX) cell ${ }^{-1}$ (Parkhill and Cembella 1999) at the end of the exponential growth phase in the present study. The non-toxic diatom, $T$. weissflogii, was chosen to represent the nanoplankton community that dominates during the presence of $A$. catenella in the Thau basin.

\subsection{Experimental design}

\subsubsection{Crassostrea virginica exposed to Alexandrium fundyense}

This experiment was conducted as part of a screening program for dinoflagellate effects on molluscs. Oysters were sorted randomly, eight into each of 12, 1.2-I basins (three replicates of four different microalgal treatments), with a continuous flow of $2 \mathrm{ml} \mathrm{min}^{-1}$ of: (1) $5 \times 10^{2}$ cells ml ${ }^{-1}$ Alexandrium fundyense, (2) $1 \times 10^{2}$ cells $\mathrm{ml}^{-1} \mathrm{~A}$. fundyense, (3) $2.5 \times 10^{2}$ cells ml ${ }^{-1} \mathrm{~A}$. fundyense plus $2.5 \times 10^{2}$ cells $\mathrm{ml}^{-1}$ Thalassiosira weissflogii, or (4) $5 \times 10^{3}$ cells $\mathrm{ml}^{-1} \mathrm{~T}$. weissflogii. All hemocyte parameters listed above were analyzed in triplicate for each group of oysters after 7 days of exposure to the different diets. No toxin analyses were done for these oysters.

\subsubsection{Crassostrea gigas exposed to Alexandrium catenella}

This experiment, conducted to determine toxin accumulation rates under various experimental conditions, presented an opportunity to conduct hemocyte analyses. Oysters were sorted randomly, one into each of 20 individual basins described in several previous studies (Bougrier et al., 2001, 2003), which were supplied with a continuous flow on a 24-h sequence of cycling microalgal flows: 1.5 × $10^{3}$ cells ml ${ }^{-1} T$. weissflogii and 75 cells mll $^{-1} A$. catenella for $14 \mathrm{~h}$, and then $1.5 \times 10^{3}$ cells mll $^{-1} T$. weissflogii and $1.5 \times 10^{2}$ cells $\mathrm{ml}^{-1} \mathrm{~A}$. catenella, for $10 \mathrm{~h}^{-1} \mathrm{y}^{-1}$ over $4 \mathrm{~d}$. Cell concentrations, including diurnal fluctuations. of $A$. catenella, for these experiments were equivalent to those observed in natural blooms recorded on the Catalogne coast in the summers 1998 and 1999, wherein A. catenella cell concentrations varied between $10^{4}$ and $10^{6}$ cells I $^{-1}$ (Vila et al., 2001). The concentrations of $A$. 
catenella and $T$. weissflogii were monitored with a Coulter Multisizer and a microscope (using an Utermohl counting chamber) every morning during two experiments conducted at $12^{\circ} \mathrm{C}$ or $18^{\circ} \mathrm{C}$ with oysters pre-conditioned for $5 \mathrm{~d}$ to each temperature. These temperatures represent the coldest and the warmest temperatures generally observed in the Thau basin during blooms of $A$. catenella.

Hemocyte responses, as listed below, were analyzed in oysters sub-sampled from the basins as follows: (1) four individuals after a 1-d exposure, (2) four after a 2-d exposure, (3) four after a 3-d exposure, and (4) eight after a 4-d exposure. In addition, eight control oysters, which were not exposed to $A$. catenella and were not transferred to the basins, were analyzed; these are reported as "Day 0" in the analysis of results and on the figures.

\subsection{Paralysis determination}

Paralysis of oysters was assessed semi-quantitatively by observation of the oysters' shell gape. Gaping oysters were stimulated mechanically with a micropipette on the gills and adductor muscle. If oysters did not react with any movement, they were considered paralyzed. Viability of paralyzed oysters was determined by observation of water movement in the shell cavity and subsequent recovery of muscle function after removal from $A$. fundyense exposure.

\subsection{Toxin analysis}

Analysis for PSP toxins in Alexandrium catenella and in PSP-contaminated oysters was performed by reverse-phase, ion-pairing, high-performance liquid chromatography (IP-HPLC) according to the method of Oshima (1989). Total soft tissues of oysters were minced in $\mathrm{HCl}(0.1 \mathrm{~N}$ at $\left.4^{\circ} \mathrm{C}\right)$. After centrifugation $\left(3,000 \times \mathrm{g}, 15 \mathrm{~min}, 4^{\circ} \mathrm{C}\right)$, the $\mathrm{pH}$ of extracts was adjusted to $3.0-3.5$ with $12 \mathrm{~N}$ $\mathrm{HCl}$. After half-dilution, supernatants were ultrafiltered (20,000 Da, Sartorius Centrisart) and stored at $4^{\circ} \mathrm{C}$ until analysis. Diluted solutions of each compound of PSP1-B reference material (MACSP, NRCHalifax, Canada) were used as external standards for quantitative detection. In consideration of the dilution factors, the molar concentrations were converted to saxitoxin-equivalents, $\mu \mathrm{g} \mathrm{STX} \mathrm{Eq.} 100 \mathrm{~g}^{-1}$ of bivalve tissue by using the conversion factors of Oshima (1995), i.e. $297 \mu$ g.STX.eq. $\mu \mathrm{M}$ for GTX3, 168 for GTX2, 48 for C1 and C2, 28 for B1; and 354 for GTX4. For A. catenella toxins, a few (B1, C1, C2) are quantified indirectly after acid hydrolysis (Masselin et al., 2001).

\subsection{Hemocyte morphology and functions}

Flow-cytometric analyses of hemocyte morphological characteristics and functions were conducted on hemolymph extracted from the oysters. Prior to hemolymph sampling, a notch was ground in the ventral edges of $C$. virginica shells, and oysters were returned to flowing, ultrafiltered seawater flow for one or two days to clear shell pieces from the mantle cavity. For bleeding C. gigas, a notch was made in the shell with pliers immediately before hemolymph extraction. Hemolymph was withdrawn from the adductor muscle of each oyster using a needle and 1-ml syringe and stored temporarily in an Eppendorf microcentrifuge tube on ice to retard cell clumping.

In the Milford experiment, hemolymph from 4 oysters was pooled (Hégaret et al., 2003a) for the flow-cytometric analyses of all hemocyte parameters. In the Nantes experiments, hemolymph from each individual oyster was analyzed to examine the relationships between hemocyte parameters and toxin content.

Procedures for characterization of Crassostrea virginica hemocytes were modified slightly from those of Hégaret et al. (2003b) and for function (mortality, phagocytosis, and reactive oxygen species [ROS] production) according to the methods of Hégaret et al. (2003a). Concentrations and viability of sub-population hemocytes and phagocytic activity in C. gigas were measured according to Delaporte et al. (2003) and Delaporte (2005). Production of reactive oxygen species in C. gigas hemocytes was assessed in seawater according to Lambert et al. (2003). Either a FACScan (Milford) or FACSCalibur (Nantes) (BD Biosciences, San Diego, California; use of trade names does not imply endorsement) flow-cytometer was used for all hemocyte analyses.

\subsection{Statistical analysis}

Results of Milford and Nantes experiments were analyzed statistically using regression analyses, linear and rank correlation matrices, and ANOVA, with the hemocyte parameters as dependent variables and the feeding treatments, temperature, toxin accumulation, and days of 
exposure as independent variables. We used Statgraphics Plus statistical software (Manugistics, Inc., Rockville, Maryland, USA). Results were considered significant when the P-value was $<0.05$ and highly significant if $<0.01$.

\section{Results}

\subsection{Paralysis of the oysters}

Adductor-muscle paralysis was observed in $C$. virginica fed $A$. fundyense. Indeed, after $4 \mathrm{~d}$ of exposure to the high concentration of $A$. fundyense and the mixed diet, the oysters did not close their shells when stimulated mechanically; 5 - to 6-d exposures were necessary to paralyse the oysters fed the low $A$. fundyense diet. The oysters were agape, with gills extended, but they did not react to mechanical perturbation. Only hemolymph withdrawal with needle and syringe caused a slow and delayed shell-closure response. After $6 \mathrm{~d}$ of exposure, $40 \%$ of the oysters $(n=10)$ subjected to a high concentration of $A$. fundyense were paralyzed. Sixteen percent of the oysters $(n=4)$ fed the mixed diet of $A$. fundyense and $T$. weissflogii, and only $5 \%$ of the oysters $(n=1)$ fed the low concentration of $A$. fundyense were paralysed. In contrast, no paralysis was observed in oysters fed only $T$. weissflogii for $6 \mathrm{~d}$.

\subsection{Toxin accumulation}

Toxin accumulation in the soft tissues of individual $C$. gigas in the presence of $A$. catenella was quantified; oysters held at $18^{\circ} \mathrm{C}$ accumulated significantly more toxin (ANOVA, $\mathrm{P}<0,001$ ) than those exposed to the same microalgae at $12^{\circ} \mathrm{C}$ (Fig. 1). Moreover, the amount of toxin present in the oysters increased with days of exposure (Fig. 1). A regression analysis of toxin accumulation with time of exposure shows a significant increase in toxin, measured as saxitoxin-equivalents, in the tissues of the oysters at $18^{\circ} \mathrm{C}(\mathrm{P}<0.01)$; the same regression was not statistically significant at $12^{\circ} \mathrm{C}$.

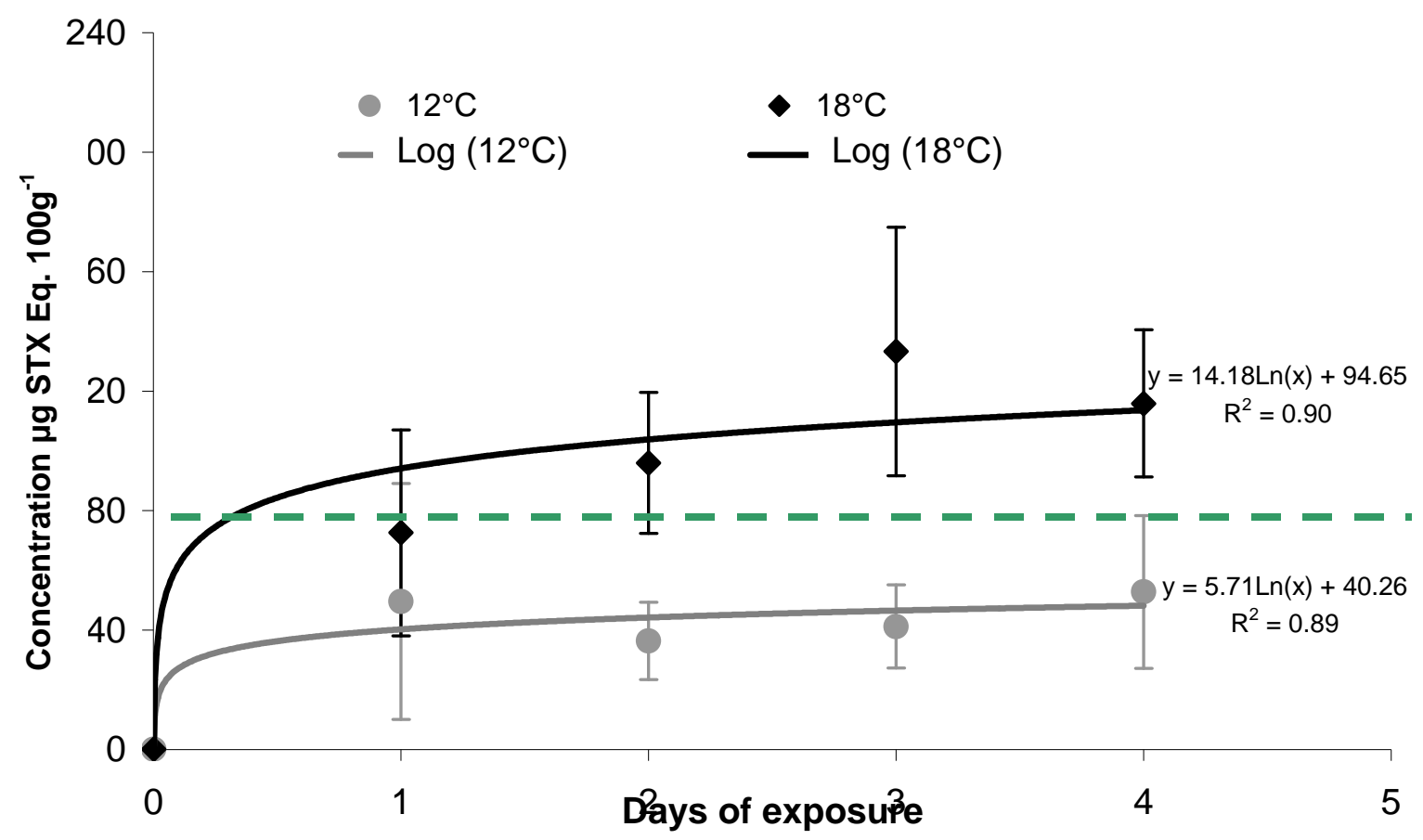

Figure 1 Crassostrea gigas. Toxin accumulation, measured in STX equivalent in tissues of oysters according to days and the temperature of exposure. Dashed line: threshold for human consumption limit 


\subsection{Hemocyte parameter analysis}

In the Milford experiment exposing Crassostrea virginica to several concentrations of Alexandrium fundyense, three different types of hemocytes were detected: granulocytes and small and large hyalinocytes. The type of algal exposure had no significant effect (ANOVA, $p>0.05$ ) on any hemocyte characteristic measured after a 7-d exposure: hemocyte numbers and percentages (granulocytes and hyalinocytes), percentage of dead hemocytes, percentage of hemocyte phagocytosis, and reactive oxygen species (ROS) production of the hemocytes (granulocytes and hyalinocytes).

The time of exposure of Crassostrea gigas to Alexandrium catenella had no statisticallysignificant effect on hemocyte parameters. An ANOVA was run with time of exposure (0-4 d) as the independent variable and each hemocyte parameter as the dependent variable. These ANOVAs included all the data from all oysters tested: $12^{\circ} \mathrm{C}$ and $18^{\circ} \mathrm{C}$, control. The hemocyte functions and characteristics analyzed as the dependant variables were: (1) hemocyte concentrations and (2) percentages of the three populations of hemocytes detected (i.e., granulocytes, hyalinocytes, and agranulocytes), (3) percentage of dead hemocytes, (4) percentage of phagocytic hemocytes, and (5) ROS production in the three hemocyte cell populations. There was no significant effect of the time of exposure of the oysters to $A$. catenella on any hemocyte parameter.

Relationships between toxin accumulation in individual $C$. gigas and the morphological or functional hemocyte measurements were also assessed using regression analysis, correlation analysis, and correlation analysis with ranked data at both temperatures combined or individually. Regression analyses were done on the oysters that had been exposed to $A$. catenella for $0,1,2,3$, or $4 \mathrm{~d}$, and between toxin accumulation and each individual hemocyte parameter. Only one regression analysis showed a significant relationship between a hemocyte measure and tissue toxin content; in oysters held at $18^{\circ} \mathrm{C}$, the percentage of dead hemocytes was positively correlated with tissue toxin accumulation (Fig. 2). This relationship was not significant at $12^{\circ} \mathrm{C}$ or when data from both temperatures were combined.

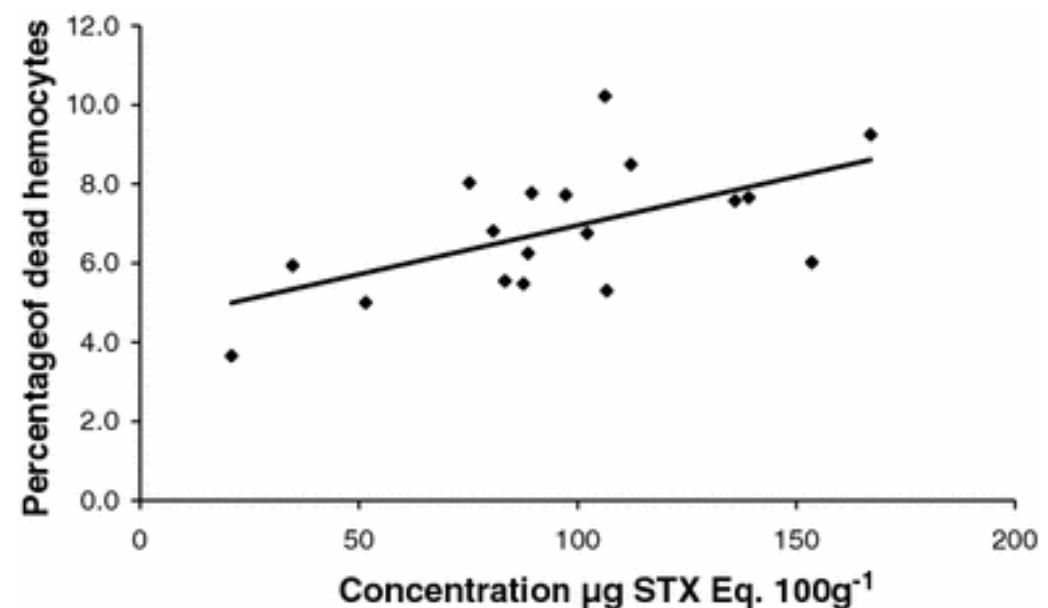

Figure 2 Crassostrea gigas. Regression analysis $\left(R^{2} 0.34, P<0.05\right)$ of percentage of dead hemocytes in oysters exposed to Alexandrium catenella at $18^{\circ} \mathrm{C}$ with tissue toxin accumulation in STX Eq. 100 $\mathrm{mg}^{-1}$.

As most regression analyses of hemocyte parameters versus toxin accumulation in C. gigas tissues were not significant, less-restrictive, simple correlation analyses were run with all hemocyte parameters and the toxin content in the tissues (Table 1). At $12^{\circ} \mathrm{C}$, or with data from both temperatures combined, no correlation was significant. At $18^{\circ} \mathrm{C}$, a significant, positive correlation was found between the percentage of dead hemocytes and toxin accumulation, as seen with regression analysis. To detect any non-linear relationships between toxin accumulation in the tissues and changes in hemocyte parameters, ranked correlations were tested (Table 1). Once again, at $18^{\circ} \mathrm{C}$, there was a positive correlation between percentage of dead hemocytes and toxin content in the 
tissues. Moreover, when data from the two temperatures were combined, there was also a positive correlation between toxin accumulation and concentration of hemocytes $(P<0.05)$, especially the concentrations of granulocytes $(P<0.01)$ and small hyalinocytes $(P<0.01)$.

Table 1. Crassostrea gigas. Results of correlation analysis between several hemocyte parameters and toxin concentrations in tissues of oysters*. First line represents correlation analysis with raw data; second line the correlation analysis with ranked data. Table includes correlation coefficient $\left(R^{2}\right)$, number of observations (parentheses) and the P-value for tests.

\begin{tabular}{llll}
\hline Hemocyte parameters & Both temperatures & $\mathbf{1 2}^{\circ} \mathbf{C}$ & $\mathbf{1 8}^{\circ} \mathbf{C}$ \\
\hline Concentration of hemocytes & NS & NS & NS \\
& $0.36(38) 0.04$ & NS & NS \\
Concentration of granulocytes & NS & NS & NS \\
& $0.33(38) 0.04$ & NS & NS \\
Percentage dead hemocytes & NS & NS & $0.58(18) 0.01$ \\
& NS & NS & $0.50(18) 0.04$
\end{tabular}

*The following hemocyte parameters were analyzed and showed no significant difference under any circumstances: Concentration of large hyalinocytes, percentage of granulocytes, percentage of large hyalinocytes, percentage of small hyalinocytes, production of ROS by granulocytes, production of ROS by large hyalinocytes, production of ROS by small hyalinocytes, and percentage of phagocytosis

\section{Discussion}

In the two experiments, there was almost no effect of Alexandrium spp. on the measured hemocyte parameters of Crassostrea virginica or Crassostrea gigas. Indeed, eastern oyster (C. virginica) hemocytes had the same characteristics after being fed Thalassiosira weissflogii, a mix of $T$. weissflogii and Alexandrium fundyense, or $A$. fundyense at two different concentrations. Despite this absence of effect on the hemocyte parameters, a clear physiological effect of $A$. fundyense on $C$. virginica was observed, specifically adductor-muscle paralysis of some oysters fed the higher concentration of $A$. fundyense after $4 \mathrm{~d}$, and after 5 to $6 \mathrm{~d}$ for the oysters fed the mix and the low concentration.

Similarly, there was almost no apparent effect of $A$. catenella on the $C$. gigas hemocyte parameters tested. The hemocyte parameters appeared to be independent of the time of exposure to A. catenella. Moreover, in most cases hemocyte parameters also appeared to be independent of the toxin accumulation in the tissues of the oysters. Based upon ranked correlation analysis, oysters that accumulated more toxins at $18^{\circ} \mathrm{C}$ tended to have a higher percentage of dead hemocytes, and also a higher concentration of circulating, live hemocytes. Because the numeric correlation was not significant, the changes in hemocytes were not quantitatively proportional to the magnitude of toxin accumulation in the tissues, although oysters with higher toxin contents also tended to be those with higher hemocyte concentrations and more dead hemocytes. Accumulation of dead cells and the increase in hemocyte number may indicate that hemocyte turnover and recycling was slowed as oysters accumulated more toxins, or it may indicate that oysters with higher concentrations of circulating hemocytes, including dead cells, were also those that tended to accumulate more toxin. Toxin accumulation is a function of both assimilation and depuration; therefore, differences in individual oyster metabolic rate could be related to variation in rates of both toxin depuration and hemocyte turnover. This relationship with metabolic rate is supported by the observation that the effect was significant at $18^{\circ} \mathrm{C}$, but not $12^{\circ} \mathrm{C}$ and by a previous study demonstrating a positive relationship between heart rate and concentration of circulating hemocytes (Feng 1965).

PSP toxins are known to be neurotoxins that exert their effects by blocking sodium-channel function at neural synapses (Catterall 1980), and the adductor-muscle paralysis in Crassostrea virginica after feeding on $A$. fundyense is consistent with this knowledge. Moreover, our finding of no effect of PSP-containing Alexandrium spp. on the measured hemocyte characteristics may suggest that sodium-channel physiology does not play an important role in these particular functions. 
A dinoflagellate species may produce a diverse array of bioactive chemical compounds, some functioning as allelochemicals affecting other phytoplankton (Tillmann and John, 2002) and others that may serve as grazing deterrents (Delgado and Alcaraz, 1999). Our findings of no effect of two different Alexandrium species upon certain hemocyte properties in two different oyster species exposed in the laboratory indicate that there are apparently no chemical products other than the known PSP toxins in these Alexandrium species that affect oyster hemocytes.

Practically, the finding of no effect of Alexandrium spp. on most hemocyte parameters indicates that oysters experiencing toxic Alexandrium blooms are ikely to have functional hemocytes to respond to pathogens or parasites, at least during short-term (time scale of days) blooms. Chronic effects of long-term or repeated exposures of oysters to PSP toxins remain to be explored. Further, field studies of oysters during natural, toxic dinoflagellate blooms are needed to confirm these experimental data under environmental conditions that may present multiple stresses.

\section{Acknowledgements}

We thank Jennifer Alix, Mark Dixon, Barry Smith, Philippe Truquet and Michèle Bardouil for their help conducting the experiments. 


\section{References}

Bougrier, S., Lassus, P., Baliaeff, B., Bardouil, M., Masselin, P., Truquet, P., Matignon, F., Mornet, F., Le Baut, C. 2001. Feeding behavior of individuals and groups of king scallops (Pecten maximus) contaminated experimentally with PSP toxins and detoxified. In: Hallegraeff, G.M., Blackburn, S.I., Bolch, C.J., Lewis, R.J. (eds), Harmful algal blooms 2000. IOC-UNESCO Publ, pp 407-410

Bougrier, S., Lassus, P., Bardouil, M., Masselin, P., Truquet, P. 2003. Paralytic shellfish poison accumulation yields and feeding time activity in the Pacific oyster (Crassostrea gigas) and king scallop (Pecten maximus). Aquatic Living Resources 16:347-352

Bricelj, V.M., Shumway, S.E. 1998. Paralytic shellfish toxins in bivalve molluscs. Occurrence, transfer kinetics and biotransformation. Review in Fisheries Science 6:315-383

Bricelj, V.M., Connell, L., Konoki, K., MacQuarrie, S., Scheuer, T., Catterall, W.A., Trainer V.L., 2005. Sodium channel mutation leading to saxitoxin resistance in clams increases risk of PSP. Nature 434: 763-766

Catterall, W.A. 1980. Neurotoxins that act on voltage-sensitive sodium channels in excitable membranes. Annual Review in Pharmacology and Toxicology 20:15-43

Chanock, S.J., Benna, J.E., Smith, R.M., Babior, B.M. 1994. The respiratory burst oxidase. Journal of Biological Chemistry 269: 24519-24522

Choi, M.C., Hsieh, D.P.H., Lam, P.K.S., Wang, W.X. 2003. Field depuration and biotransformation of paralytic shellfish toxins in scallop Chlamys nobilis and green-lipped mussel Perna viridis. Marine Biology143:927-934

Delaporte, M. Soudant, P., Moal, J., Lambert, C., Quere, C., Miner, P., Choquet,G., Paillard, C., Samain, J.F. 2003. Effect of a mono-specific algal diet on immune functions in two bivalve species Crassostrea gigas and Ruditapes philippinarum. J Exp Biol 206:3053-3064

Delaporte, M. 2005. Modulation des parametres hemocytaires par la nutrition chez l'huitre creuse Crassostrea gigas. Implication dans les mortalités estivales. Thèse de l'Université de Rennes 1.

Delgado, M., Alcaraz, M. 1999. Interactions between red tide microalgae and herbivorous zooplankton: the noxious effects of Gyrodinium corsicum (Dinophyceae) on Acartia grani (Copepoda: Calanoida). Journal of Plankton Research 21: 2361-2371

Feng, S.Y. 1965. Heart rate and leucocyte circulation in Crassostrea virginica (GMELIN). Biological Bulletin 128: 198-210

Gainey, L.F., Shumway, S.E. 1988a. A compendium of the responses of bivalve molluscs to toxic dinoflagellates. Journal of Shellfish Research $7: 623-628$

Gainey, L.F., Shumway, S.E. 1988b. Physiological effects of Protogonyaulax tamarensis on cardiac activity in bivalve molluscs. Comparative Biochemistry and Physiology 91C:159-164

Guillard, R.R.L., Ryther, J.H. 1962. Studies of marine planktonic diatoms. I. Cyclotella nana Hustedt and Detonula confervacea Cleve. Canadian Journal of Microbiology 8:229-239

Hallegraeff, G.M. 2003. Harmful algal blooms: a global overview. In Hallegraeff, G.M., Anderson, D.M., Cembella, A.D. (eds): Manual on harmful marine microalgae UNESCO publishing, pp 25-49

Hégaret, H., Wikfors, G.H. 2005a. Time-dependent changes in hemocytes of eastern oysters, Crassostrea virginica, and northern bay scallops, Argopecten irradians irradians, exposed to a cultured strain of Prorocentrum minimum. Harmful Algae 4:187-199

Hégaret, H., Wikfors, G.H. 2005b. Effects of natural and field-simulated blooms of the dinoflagellate Prorocentrum minimum upon hemocytes of eastern oysters, Crassostrea virginica, from two different populations. Harmful Algae 4: 201-209

Hégaret, H., Wikfors, G.H., Soudant P. 2003a. Flow cytometric analysis of haemocytes from eastern oysters, Crassostrea virginica, subjected to a sudden temperature elevation II. Haemocyte functions: aggregation, viability, phagocytosis, and respiratory burst. Journal of Experimental Marine Biology and Ecology 293:249-265

Hégaret, H., Wikfors, G.H. Soudant P. 2003b. Flow-cytometric analysis of haemocytes from eastern oysters, Crassostrea virginica, subjected to a sudden temperature elevation I. Haemocyte types and morphology. Journal of Experimental Marine Biology and Ecology 293:237-248

Janeway, C.A. 1994. The role of microbial pattern recognition in self:nonself discrimination in innate and adaptive immunity. In Hoffmann, J.A., Janeway, C.A., Natori, S. (eds): Phylogenetic perspectives in immunity, the insect host defence; RG Landes Company, Austin, TX, pp 115-122

Knight, J.A. 2000. Review: Free radicals,antioxidants, and the immune system. Annals of Clinical and Laboratory Science 30: 145-159 
Lambert, C., Soudant, P., Choquet, G., Paillard, C. 2003. Measurement of Crassostrea gigas hemocyte oxidative metabolism by flow cytometry and the inhibiting capacity of pathogenic vibrios. Fish and Shellfish Immunology 15: 225-240

Lassus, P., Bardouil, M., Ledoux, M., Bohec, M., Murail, I., Fremy, J.M. 1996. Role of the kidneys in bioaccumulation of paralytic toxins by scallop (Pecten maximus) tissues. Journal of Natural Toxins 5:107-115

Lassus, P., Bardouil, M., Beliaeff, B., Masselin, P., Naviner, M., Truquet, P. 1999. Effect of a continuous supply of the toxic dinoflagellate Alexandrium minutum Halim on the feeding behavior of the Pacific oyster (Crassostrea gigas Thunberg). J Shellfish Res 18:211-216

Lesser, M.P., Shumway, S.E. 1993. Effects of toxic dinoflagellates on clearance rates and survival in juvenile bivalve molluscs. Journal of Shellfish Research 12:377-381

Li, S.C., Wang, W.X., Hsieh, D.P.H. 2002. Effects of toxic dinoflagellate Alexandrium tamarense on the energy budgets and growth of two marine bivalves. Marine Environmental Research 53:145-160

Lilly, E.L., Kulis, D.M., Gentien, P., Anderson, D.M. 2002. Paralytic shellfish poisoning toxins in France linked to a human-introduced strain of Alexandrium catenella from the western Pacific: evidence from DNA and toxin analysis. Journal of Plankton Research 24:443-452

Masselin, P., Amzil, Z., Abadie, E., Carreras, A., Chiantella, C., Le Bec, C. Nézan, E., Truquet, P., 2001. Paralytic shellfish poisoning on the French Mediterranean coast in autumn 1998: Alexandrium tamarense complex (Dinophyceae) as causative agent. In Hallegraeff, G.M., Blackburn, S.I., Bolch, C.J., Lewis, R.J. (eds): Harmful Algal Blooms 2000, IOC of Unesco Publish. 26-29

Nell, J.A. 2002. Farming triploid oysters. Aquaculture 210:69-88

Oshima, Y., Sugino, K., Yasumoto, T. 1989. Latest advances in HPLC analysis of paralytic shellfish toxins, In Natori, S., Hashimoto, K., Ueno, Y. (eds): Mycotoxins and phycotoxins 88, Elsevier, Amsterdam 319-326

Oshima, Y. 1995. Chemical and enzymatic transformation of paralytic shellfish toxins in marine organisms. In Lassus, P., Arzul, G., Erard, E., Gentien, P., Marcaillou, C., (eds): Harmful marine algal blooms Lavoisier 475-480

Parkhill, J.P., Cembella, A.D. 1999. Effects of salinity, light, and inorganic nitrogen on growth and toxigenicity of the marine dinoflagellate Alexandrium tamarense from northeastern Canada. Journal of Plankton Research 21, 939-955.

Provasoli, L. 1966. Media and prospects for the cultivation of marine algae. In Watanabe, A., Hattori, A. (eds): Cultures and collections of algae, Proc U.S.-Japan Conf, Hakone, Sept 1966, Japanese Society of Plant Physiologists $\mathrm{p}$ 63-75

Shumway, S.E. 1990. A review of the effects of algal blooms on shellfish and aquaculture. Journal of World Aquaculture Society 21:65-104

Shumway, S.E., Cucci, T.L. 1987. The effect of the toxic dinoflagellate Protogonyaulax tamarensis on the feeding behavior of bivalve molluscs. Aquatic Toxicology 10:9-27

Shumway, S.E., Sherman-Caswell, S., Hurst, J.W. 1988. Paralytic shellfish poisoning in Maine: Monitoring a monster. Journal of Shellfish Research $7: 643-652$

Tillmann, U., John, U. 2002. Toxic effects of Alexandrium spp. on heterotrophic dinoflagellates: an allochemical defence mechanism independent of PSP-toxin content. Marine Ecology Progress Series 230:47-58

Ukeles, R. 1973. Continuous culture - a method for the production of unicellular algal foods. In: Stein, J.R. (ed) Handbook of phycological methods: Culture methods and growth measurements. Cambridge University Press, Cambridge pp 233-255

Vila, M., Delgado, M., Camp, J. 2001. First detection of widespread toxic events caused by Alexandrium catenella in the Mediterranean sea. In Hallegraeff, G.M., Blackburn, S.I., Bolch, C.J. and Lewis, R.J. (eds): Harmful Algal Blooms 2000, IOC of Unesco Publish. 8-11 